\title{
Relaxin family peptide receptors in GtoPdb v.2021.3
}

\author{
Ross Bathgate ${ }^{1}$, Thomas Dschietzig ${ }^{2}$, Andrew L. Gundlach ${ }^{1}$, Michelle Halls ${ }^{3}$ and Roger Summers ${ }^{3}$ \\ 1. University of Melbourne, Australia \\ 2. Charité-University Medicine Berlin, Germany \\ 3. Monash University, Australia
}

\begin{abstract}
Relaxin family peptide receptors (RXFP, nomenclature as agreed by the $\underline{\text { NC-IUPHAR }}$

Subcommittee on Relaxin family peptide receptors [18, 81]) may be divided into two pairs, RXFP1/2 and RXFP3/4. Endogenous agonists at these receptors are heterodimeric peptide hormones structurally related to insulin: relaxin-1, relaxin, relaxin-3 (also known as INSL7), insulin-like peptide 3 (INSL3) and INSL5. Species homologues of relaxin have distinct pharmacology and relaxin interacts with RXFP1, RXFP2 and RXFP3, whereas mouse and rat relaxin selectively bind to and activate RXFP1 [184]. relaxin-3 is the ligand for RXFP3 but it also binds to RXFP1 and RXFP4 and has differential affinity for RXFP2 between species [183]. INSL5 is the ligand for RXFP4 but is a weak antagonist of RXFP3. relaxin and INSL3 have multiple complex binding interactions with RXFP1 [189] and RXFP2 [91] which direct the N-terminal LDLa modules of the receptors together with a linker domain to act as a tethered ligand to direct receptor signaling [186]. INSL5 and relaxin3 interact with their receptors using distinct residues in their B-chains for binding, and activation, respectively [225, 104].
\end{abstract}

\section{Contents}

This is a citation summary for Relaxin family peptide receptors in the Guide to Pharmacology database (GtoPdb). It exists purely as an adjunct to the database to facilitate the recognition of citations to and from the database by citation analyzers. Readers will almost certainly want to visit the relevant sections of the database which are given here under database links.

GtoPdb is an expert-driven guide to pharmacological targets and the substances that act on them. GtoPdb is a reference work which is most usefully represented as an on-line database. As in any publication this work should be appropriately cited, and the papers it cites should also be recognized. This document provides a citation for the relevant parts of the database, and also provides a reference list for the research cited by those parts. For further details see [28].

Please note that the database version for the citations given in GtoPdb are to the most recent preceding version in which the family or its subfamilies and targets were substantially changed. The links below are to the current version. If you need to consult the cited version, rather than the most recent version, please contact the GtoPdb curators.

\section{Database links}

Relaxin family peptide receptors

https://www.guidetopharmacology.org/GRAC/FamilyDisplayForward?familyId=60

Introduction to Relaxin family peptide receptors

https://www.guidetopharmacology.org/GRAC/FamilyIntroductionForward?familyId=60

Receptors

RXFP1

https://www.guidetopharmacology.org/GRAC/ObjectDisplayForward?objectId=351

RXFP2

https://www.guidetopharmacology.org/GRAC/ObjectDisplayForward?objectId=352

RXFP3

https://www.guidetopharmacology.org/GRAC/ObjectDisplayForward?objectId=353

RXFP4 


\section{References}

1. Ahmad N, Wang W, Nair R and Kapila S. (2012) Relaxin induces matrix-metalloproteinases-9 and -13 via RXFP1: induction of MMP-9 involves the PI3K, ERK, Akt and PKC- $\zeta$ pathways. Mol Cell Endocrinol 363: 46-61 [PMID:22835547]

2. Albert-Gasco H, Sanchez-Sarasua S, Ma S, García-Díaz C, Gundlach AL, Sanchez-Perez AM and Olucha-Bordonau FE. (2019) Central relaxin-3 receptor (RXFP3) activation impairs social recognition and modulates ERK-phosphorylation in specific GABAergic amygdala neurons. Brain Struct Funct 224: 453-469 [PMID:30368554]

3. Alexiou K, Wilbring M, Matschke K and Dschietzig T. (2013) Relaxin protects rat lungs from ischemia-reperfusion injury via inducible NO synthase: role of ERK-1/2, PI3K, and forkhead transcription factor FKHRL1. PLOS ONE 8: e75592 [PMID:24098703]

4. Alvarez-Jaimes L, Sutton SW, Nepomuceno D, Motley ST, Cik M, Stocking E, Shoblock J and Bonaventure P. (2012) In vitro pharmacological characterization of RXFP3 allosterism: an example of probe dependency. PLoS ONE 7: e30792 [PMID:22347403]

5. Anand-Ivell R, Heng K, Bartsch O and Ivell R. (2007) Relaxin signalling in THP-1 cells uses a novel phosphotyrosine-dependent pathway. Mol Cell Endocrinol 272: 1-13 [PMID:17509748]

6. Anand-Ivell R, Tremellen K, Dai Y, Heng K, Yoshida M, Knight PG, Hale GE and Ivell R. (2013) Circulating insulin-like factor 3 (INSL3) in healthy and infertile women. Hum Reprod 28: 3093102 [PMID:24014601]

7. Anand-Ivell RJ, Relan V, Balvers M, Coiffec-Dorval I, Fritsch M, Bathgate RA and Ivell R. (2006) Expression of the Insulin-Like Peptide 3 (INSL3) Hormone-Receptor (LGR8) System in the Testis. Biol Reprod 74: 945-953 [PMID:16467492]

8. Ang SY, Evans BA, Poole DP, Bron R, DiCello JJ, Bathgate RAD, Kocan M, Hutchinson DS and Summers RJ. (2018) INSL5 activates multiple signalling pathways and regulates GLP-1 secretion in NCI-H716 cells. J Mol Endocrinol 60: 213-224 [PMID:29535183]

9. Ang SY, Hutchinson DS, Patil N, Evans BA, Bathgate RAD, Halls ML, Hossain MA, Summers RJ and Kocan M. (2017) Signal transduction pathways activated by insulin-like peptide 5 at the relaxin family peptide RXFP4 receptor. Br J Pharmacol 174: 1077-1089 [PMID:27243554]

10. Baccari MC, Bani D, Bigazzi M and Calamai F. (2004) Influence of relaxin on the neurally induced relaxant responses of the mouse gastric fundus. Biol Reprod 71: 1325-9 [PMID:15215200]

11. Baccari MC, Nistri S, Quattrone S, Bigazzi M, Bani Sacchi T, Calamai F and Bani D. (2004) Depression by relaxin of neurally induced contractile responses in the mouse gastric fundus. Biol Reprod 70: 222-8 [PMID:14522837]

12. Baccari MC, Nistri S, Vannucchi MG, Calamai F and Bani D. (2007) Reversal by relaxin of altered ileal spontaneous contractions in dystrophic $(\mathrm{mdx})$ mice through a nitric oxide-mediated mechanism. Am J Physiol Regul Integr Comp Physiol 293: R662-8 [PMID:17522128]

13. Banerjee A, Shen PJ, Ma S, Bathgate RA and Gundlach AL. (2010) Swim stress excitation of nucleus incertus and rapid induction of relaxin-3 expression via CRF1 activation. Neuropharmacology 58: 145-55 [PMID:19560474]

14. Bani D, Failli P, Bello MG, Thiemermann C, Bani Sacchi T, Bigazzi M and Masini E. (1998) Relaxin activates the L-arginine-nitric oxide pathway in vascular smooth muscle cells in culture. Hypertension 31: 1240-7 [PMID:9622136]

15. Bartsch O, Bartlick B and Ivell R. (2001) Relaxin signalling links tyrosine phosphorylation to phosphodiesterase and adenylyl cyclase activity. Mol Hum Reprod 7: 799-809 [PMID:11517286]

16. Bartsch O, Bartlick B and Ivell R. (2004) Phosphodiesterase 4 inhibition synergizes with relaxin signaling to promote decidualization of human endometrial stromal cells. J Clin Endocrinol Metab 89: 324-34 [PMID:14715868]

17. Bathgate RA, Halls ML, van der Westhuizen ET, Callander GE, Kocan M and Summers RJ. (2013) Relaxin family peptides and their receptors. Physiol Rev 93: 405-80 [PMID:23303914]

18. Bathgate RA, Ivell R, Sanborn BM, Sherwood OD and Summers RJ. (2006) International Union of Pharmacology LVII: recommendations for the nomenclature of receptors for relaxin family peptides. Pharmacol Rev 58: 7-31 [PMID:16507880]

19. Bathgate RA, Lin F, Hanson NF, Otvos L, Guidolin A, Giannakis C, Bastiras S, Layfield SL, Ferraro T, Ma S, Zhao C, Gundlach AL, Samuel CS, Tregear GW and Wade JD. (2006) Relaxin-3: Improved Synthesis Strategy and Demonstration of Its High-Affinity Interaction with the Relaxin Receptor LGR7 Both In Vitro and In Vivo. Biochemistry 45: 1043-1053 [PMID:16411781]

20. Bathgate RA, Samuel CS, Burazin TC, Layfield S, Claasz AA, Reytomas IG, Dawson NF, Zhao C, Bond C and Summers RJ et al.. (2002) Human relaxin gene 3 (H3) and the equivalent mouse relaxin (M3) gene. Novel members of the relaxin peptide family. J Biol Chem 277: 1148-57 [PMID:11689565]

21. Bathgate RAD, Hsueh AJW and Sherwood OD. (2005) Physiology and molecular biology of the 
relaxin peptide family. In Physiology of Reproduction Edited by Knobil E, Neill JD: Elsevier: 679968 [ISBN: 0125154003]

22. Belgi A, Bathgate RA, Kocan M, Patil N, Zhang S, Tregear GW, Wade JD and Hossain MA. (2013) Minimum active structure of insulin-like peptide 5. J Med Chem 56: 9509-16 [PMID:24188028]

23. Belgi A, Hossain MA, Shabanpoor F, Chan L, Zhang S, Bathgate RA, Tregear GW and Wade JD. (2011) Structure and function relationship of murine insulin-like peptide 5 (INSL5): free Cterminus is essential for RXFP4 receptor binding and activation. Biochemistry 50: 8352-61 [PMID:21866895]

24. Bigazzi M, Brandi ML, Bani G and Sacchi TB. (1992) Relaxin influences the growth of MCF-7 breast cancer cells. Mitogenic and antimitogenic action depends on peptide concentration. Cancer 70: 639-43 [PMID:1320450]

25. Boels K and Schaller HC. (2003) Identification and characterisation of GPR100 as a novel human G-protein-coupled bradykinin receptor. Br J Pharmacol 140: 932-8 [PMID:14530218]

26. Bond CP, Parry LJ, Samuel CS, Gehring HM, Lederman FL, Rogers PA and Summers RJ. (2004) Increased expression of the relaxin receptor (LGR7) in human endometrium during the secretory phase of the menstrual cycle. J Clin Endocrinol Metab 89: 3477-85 [PMID:15240635]

27. Braddon SA. (1978) Relaxin-dependent adenosine 6',5'-monophosphate concentration changes in the mouse pubic symphysis. Endocrinology 102: 1292-9 [PMID:217619]

28. Buneman P, Christie G, Davies JA, Dimitrellou R, Harding SD, Pawson AJ, Sharman JL and Wu Y. (2020) Why data citation isn't working, and what to do about it Database 2020 [PMID:32367113]

29. Büllesbach EE and Schwabe C. (2005) LGR8 signal activation by the relaxin-like factor. J Biol Chem 280: 14586-90 [PMID:15708846]

30. Calvez J, de Ávila C, Matte LO, Guèvremont G, Gundlach AL and Timofeeva E. (2016) Role of relaxin-3/RXFP3 system in stress-induced binge-like eating in female rats. Neuropharmacology 102: 207-15 [PMID:26607097]

31. Calvez J, Lenglos C, de Ávila C, Guèvremont G and Timofeeva E. (2015) Differential effects of central administration of relaxin-3 on food intake and hypothalamic neuropeptides in male and female rats. Genes Brain Behav 14: 550-63 [PMID:26234422]

32. Cardoso LC, Nascimento AR, Royer C, Porto CS and Lazari MF. (2010) Locally produced relaxin may affect testis and vas deferens function in rats. Reproduction 139: 185-96 [PMID:19812235]

33. Chan LJ, Rosengren KJ, Layfield SL, Bathgate RA, Separovic F, Samuel CS, Hossain MA and Wade JD. (2012) Identification of key residues essential for the structural fold and receptor selectivity within the A-chain of human gene-2 (H2) relaxin. J Biol Chem 287: 41152-64 [PMID:23024363]

34. Chen GA, Huang JR and Tseng L. (1988) The effect of relaxin on cyclic adenosine 3',5'monophosphate concentrations in human endometrial glandular epithelial cells. Biol Reprod 39: 519-25 [PMID:2848594]

35. Chen J, Kuei C, Sutton SW, Bonaventure P, Nepomuceno D, Eriste E, Sillard R, Lovenberg TW and Liu C. (2005) Pharmacological characterization of relaxin-3/INSL7 receptors GPCR135 and GPCR142 from different mammalian species. J Pharmacol Exp Ther 312: 83-95 [PMID:15367576]

36. Chow BS, Chew EG, Zhao C, Bathgate RA, Hewitson TD and Samuel CS. (2012) Relaxin signals through a RXFP1-pERK-nNOS-NO-cGMP-dependent pathway to up-regulate matrix metalloproteinases: the additional involvement of iNOS. PLoS ONE 7: e42714 [PMID:22936987]

37. Chow BS, Kocan M, Bosnyak S, Sarwar M, Wigg B, Jones ES, Widdop RE, Summers RJ, Bathgate RA and Hewitson TD et al.. (2014) Relaxin requires the angiotensin II type 2 receptor to abrogate renal interstitial fibrosis. Kidney Int 86: 75-85 [PMID:24429402]

38. Civciristov S and Halls ML. (2019) Signalling in response to sub-picomolar concentrations of active compounds: Pushing the boundaries of GPCR sensitivity. Br J Pharmacol 176: 2382-2401 [PMID:30801691]

39. Conrad KP. (2010) Unveiling the vasodilatory actions and mechanisms of relaxin. Hypertension 56: 2-9 [PMID:20497994]

40. Conrad KP and Novak J. (2004) Emerging role of relaxin in renal and cardiovascular function. Am J Physiol Regul Integr Comp Physiol 287: R250-R261 [PMID:15271674]

41. Cronin MJ, Malaska T and Bakhit C. (1987) Human relaxin increases cyclic AMP levels in cultured anterior pituitary cells. Biochem Biophys Res Commun 148: 1246-51 [PMID:2446608]

42. De Toni L, Agoulnik AI, Sandri M, Foresta C and Ferlin A. (2019) INSL3 in the muscolo-skeletal system. Mol Cell Endocrinol 487: 12-17 [PMID:30625346]

43. de Ávila C, Chometton S, Lenglos C, Calvez J, Gundlach AL and Timofeeva E. (2018) Differential effects of relaxin-3 and a selective relaxin-3 receptor agonist on food and water intake and hypothalamic neuronal activity in rats. Behav Brain Res 336: 135-144 [PMID:28864207]

44. DeChristopher B, Park SH, Vong L, Bamford D, Cho HH, Duvadie R, Fedolak A, Hogan C, Honda T and Pandey P et al.. (2019) Discovery of a small molecule RXFP3/4 agonist that increases food intake in rats upon acute central administration. Bioorg Med Chem Lett 29: 991-994 
[PMID:30824200]

45. Del Borgo MP, Hughes RA, Bathgate RA, Lin F, Kawamura K and Wade JD. (2006) Analogs of insulin-like peptide 3 (INSL3) B-chain are LGR8 antagonists in vitro and in vivo. J Biol Chem: 727-729 [PMID:16547350]

46. Diepenhorst NA, Petrie EJ, Chen CZ, Wang A, Hossain MA, Bathgate RA and Gooley PR. (2014) Investigation of interactions at the extracellular loops of the relaxin family peptide receptor 1 (RXFP1). J Biol Chem 289: 34938-52 [PMID:25352603]

47. Diwakarla S, Bathgate RAD, Zhang X, Hossain MA and Furness JB. (2020) Colokinetic effect of an insulin-like peptide 5-related agonist of the RXFP4 receptor. Neurogastroenterol Motil 32: e13796 [PMID:31989750]

48. Downing SJ and Hollingsworth M. (1991) Antagonism of relaxin by glibenclamide in the uterus of the rat in vivo. Br J Pharmacol 104: 71-6 [PMID:1664766]

49. Downing SJ, McIlwrath A and Hollingsworth M. (1992) Cyclic adenosine 3'5'-monophosphate and the relaxant action of relaxin in the rat uterus in vivo. J Reprod Fertil 96: 857-63 [PMID:1339864]

50. Dschietzig T, Alexiou K, Kinkel HT, Baumann G, Matschke K and Stangl K. (2011) The positive inotropic effect of relaxin-2 in human atrial myocardium is preserved in end-stage heart failure: role of G(i)-phosphoinositide-3 kinase signaling. J Card Fail 17: 158-66 [PMID:21300306]

51. Dschietzig T, Bartsch C, Baumann G and Stangl K. (2009) RXFP1-inactive relaxin activates human glucocorticoid receptor: further investigations into the relaxin-GR pathway. Regul Pept 154: 77-84 [PMID:19101597]

52. Dschietzig T, Bartsch C, Richter C, Laule M, Baumann G and Stangl K. (2003) Relaxin, a pregnancy hormone, is a functional endothelin-1 antagonist: attenuation of endothelin-1mediated vasoconstriction by stimulation of endothelin type-B receptor expression via ERK-1/2 and nuclear factor-kappaB. Circ Res 92: 32-40 [PMID:12522118]

53. Dschietzig T, Bartsch C, Stangl V, Baumann G and Stangl K. (2004) Identification of the pregnancy hormone relaxin as glucocorticoid receptor agonist. FASEB J 18: 1536-8 [PMID:15289446]

54. Dschietzig T, Bartsch C, Wessler S, Baumann G and Stangl K. (2009) Autoregulation of human relaxin-2 gene expression critically involves relaxin and glucocorticoid receptor binding to glucocorticoid response half-sites in the relaxin-2 promoter. Regul Pept 155: 163-73 [PMID:19289144]

55. Dschietzig T, Brecht A, Bartsch C, Baumann G, Stangl K and Alexiou K. (2012) Relaxin improves TNF- $\alpha$-induced endothelial dysfunction: the role of glucocorticoid receptor and phosphatidylinositol 3-kinase signalling. Cardiovasc Res 95: 97-107 [PMID:22510373]

56. Dschietzig T, Teichman S, Unemori E, Wood S, Boehmer J, Richter C, Baumann G and Stangl K. (2009) Intravenous recombinant human relaxin in compensated heart failure: a safety, tolerability, and pharmacodynamic trial. J Card Fail 15: 182-90 [PMID:19327619]

57. Dschietzig TB. (2019) Relaxin-2 for heart failure with preserved ejection fraction (HFpEF): Rationale for future clinical trials. Mol Cell Endocrinol 487: 54-58 [PMID:30659842]

58. Fei DT, Gross MC, Lofgren JL, Mora-Worms M and Chen AB. (1990) Cyclic AMP response to recombinant human relaxin by cultured human endometrial cells--a specific and high throughput in vitro bioassay. Biochem Biophys Res Commun 170: 214-22 [PMID:1695506]

59. Feng S, Agoulnik IU, Bogatcheva NV, Kamat AA, Kwabi-Addo B, Li R, Ayala G, Ittmann MM and Agoulnik AI. (2007) Relaxin promotes prostate cancer progression. Clin Cancer Res 13: 1695702 [PMID:17363522]

60. Feng S, Agoulnik IU, Truong A, Li Z, Creighton CJ, Kaftanovskaya EM, Pereira R, Han HD, Lopez-Berestein $\mathrm{G}$ and Klonisch $\mathrm{T}$ et al.. (2010) Suppression of relaxin receptor RXFP1 decreases prostate cancer growth and metastasis. Endocr Relat Cancer 17: 1021-33 [PMID:20861284]

61. Ferlin A, Pepe A, Gianesello L, Garolla A, Feng S, Facciolli A, Morello R, Agoulnik AI and Foresta C. (2009) New roles for INSL3 in adults. Ann N Y Acad Sci 1160: 215-8 [PMID:19416191]

62. Ferlin A, Pepe A, Gianesello L, Garolla A, Feng S, Giannini S, Zaccolo M, Facciolli A, Morello R and Agoulnik AI et al.. (2008) Mutations in the insulin-like factor 3 receptor are associated with osteoporosis. J Bone Miner Res 23: 683-93 [PMID:18433302]

63. Ferlin A, Selice R, Carraro U and Foresta C. (2013) Testicular function and bone metabolism-beyond testosterone. Nat Rev Endocrinol 9: 548-54 [PMID:23856820]

64. Filonzi M, Cardoso LC, Pimenta MT, Queiróz DB, Avellar MC, Porto CS and Lazari MF. (2007) Relaxin family peptide receptors Rxfp1 and Rxfp2: mapping of the mRNA and protein distribution in the reproductive tract of the male rat. Reprod Biol Endocrinol 5: 29 [PMID:17623071]

65. Fisher C, MacLean M, Morecroft I, Seed A, Johnston F, Hillier C and McMurray J. (2002) Is the pregnancy hormone relaxin also a vasodilator peptide secreted by the heart? Circulation 106: 292-5 [PMID:12119241]

66. Foresta C and Ferlin A. (2004) Role of INSL3 and LGR8 in cryptorchidism and testicular 
functions. Reprod Biomed Online 9: 294-8 [PMID:15353080]

67. Fu P, Shen PJ, Zhao CX, Scott DJ, Samuel CS, Wade JD, Tregear GW, Bathgate RA and Gundlach AL. (2005) Detection, localization, and action of the INSL3 receptor, LGR8, in rat kidney. Ann $N$ Y Acad Sci 1041: 516-9 [PMID:15956754]

68. Ganella DE, Callander GE, Ma S, Bye CR, Gundlach AL and Bathgate RA. (2013) Modulation of feeding by chronic rAAV expression of a relaxin-3 peptide agonist in rat hypothalamus. Gene Ther 20: 703-16 [PMID:23135160]

69. Ganella DE, Ryan PJ, Bathgate RA and Gundlach AL. (2012) Increased feeding and body weight gain in rats after acute and chronic activation of RXFP3 by relaxin-3 and receptor-selective peptides: functional and therapeutic implications. Behav Pharmacol 23: 516-25 [PMID:22854307]

70. Gheorghiade M and Pang PS. (2009) Acute heart failure syndromes. J Am Coll Cardiol 53: 55773 [PMID:19215829]

71. Glister C, Satchell L, Bathgate RA, Wade JD, Dai Y, Ivell R, Anand-Ivell R, Rodgers RJ and Knight PG. (2013) Functional link between bone morphogenetic proteins and insulin-like peptide 3 signaling in modulating ovarian androgen production. Proc Natl Acad Sci USA 110: E1426-35 [PMID:23530236]

72. Glogowska A, Kunanuvat U, Stetefeld J, Patel TR, Thanasupawat T, Krcek J, Weber E, Wong GW, Del Bigio MR and Hoang-Vu C et al.. (2013) C1q-tumour necrosis factor-related protein 8 (CTRP8) is a novel interaction partner of relaxin receptor RXFP1 in human brain cancer cells. $J$ Pathol 231: 466-79 [PMID:24014093]

73. Gorlov IP, Kamat A, Bogatcheva NV, Jones E, Lamb DJ, Truong A, Bishop CE, McElreavey K and Agoulnik AI. (2002) Mutations of the GREAT gene cause cryptorchidism. Hum Mol Genet 11: 2309-18 [PMID:12217959]

74. Grosse J, Heffron H, Burling K, Akhter Hossain M, Habib AM, Rogers GJ, Richards P, Larder R, Rimmington D and Adriaenssens AA et al.. (2014) Insulin-like peptide 5 is an orexigenic gastrointestinal hormone. Proc Natl Acad Sci USA 111: 11133-8 [PMID:25028498]

75. Gundlach AL, Ma S, Sang Q, Shen PJ, Piccenna L, Sedaghat K, Smith CM, Bathgate RA, Lawrence AJ and Tregear GW et al.. (2009) Relaxin family peptides and receptors in mammalian brain. Ann N Y Acad Sci 1160: 226-35 [PMID:19416194]

76. Hagen CP, Mieritz MG, Nielsen JE, Anand-Ivell R, Ivell R and Juul A. (2015) Longitudinal assessment of circulating insulin-like peptide 3 levels in healthy peripubertal girls. Fertil Steril 103: 780-6.e1 [PMID:25516081]

77. Haidar M, Guèvremont G, Zhang C, Bathgate RAD, Timofeeva E, Smith CM and Gundlach AL. (2017) Relaxin-3 inputs target hippocampal interneurons and deletion of hilar relaxin-3 receptors in "floxed-RXFP3" mice impairs spatial memory. Hippocampus 27: 529-546 [PMID:28100033]

78. Haidar M, Tin K, Zhang C, Nategh M, Covita J, Wykes AD, Rogers J and Gundlach AL. (2019) Septal GABA and Glutamate Neurons Express RXFP3 mRNA and Depletion of Septal RXFP3 Impaired Spatial Search Strategy and Long-Term Reference Memory in Adult Mice. Front Neuroanat 13: 30 [PMID:30906254]

79. Halls ML, Bathgate RA and Summers RJ. (2006) Relaxin family peptide receptors RXFP1 and RXFP2 modulate cAMP signaling by distinct mechanisms. Mol Pharmacol 70: 214-26 [PMID:16569707]

80. Halls ML, Bathgate RA and Summers RJ. (2005) Signal switching after stimulation of LGR7 receptors by human relaxin 2. Ann N Y Acad Sci 1041: 288-91 [PMID:15956719]

81. Halls ML, Bathgate RA, Sutton SW, Dschietzig TB and Summers RJ. (2015) International Union of Basic and Clinical Pharmacology. XCV. Recent advances in the understanding of the pharmacology and biological roles of relaxin family peptide receptors 1-4, the receptors for relaxin family peptides. Pharmacol Rev 67: 389-440 [PMID:25761609]

82. Halls ML, Bond CP, Sudo S, Kumagai J, Ferraro T, Layfield S, Bathgate RA and Summers RJ. (2005) Multiple binding sites revealed by interaction of relaxin family peptides with native and chimeric relaxin family peptide receptors 1 and 2 (LGR7 and LGR8). J Pharmacol Exp Ther 313: 677-87 [PMID:15649866]

83. Halls ML and Cooper DM. (2010) Sub-picomolar relaxin signalling by a pre-assembled RXFP1, AKAP79, AC2, beta-arrestin 2, PDE4D3 complex. EMBO J 29: 2772-87 [PMID:20664520]

84. Halls ML, van der Westhuizen ET, Bathgate RA and Summers RJ. (2007) Relaxin family peptide receptors--former orphans reunite with their parent ligands to activate multiple signalling pathways. Br J Pharmacol 150: 677-91 [PMID:17293890]

85. Halls ML, van der Westhuizen ET, Wade JD, Evans BA, Bathgate RA and Summers RJ. (2009) Relaxin family peptide receptor (RXFP1) coupling to G(alpha)i3 involves the C-terminal Arg752 and localization within membrane Raft Microdomains. Mol Pharmacol 75: 415-28 [PMID:19029286]

86. Harris RM, Finlayson C, Weiss J, Fisher L, Hurley L, Barrett T, Emge D, Bathgate RA, Agoulnik AI and Jameson JL. (2010) A missense mutation in LRR8 of RXFP2 is associated with 
cryptorchidism. Mamm Genome 21: 442-9 [PMID:20963592]

87. Haugaard-Kedström LM, Lee HS, Jones MV, Song A, Rathod V, Hossain MA, Bathgate RAD and Rosengren KJ. (2018) Binding conformation and determinants of a single-chain peptide antagonist at the relaxin-3 receptor RXFP3. J Biol Chem 293: 15765-15776 [PMID:30131342]

88. Haugaard-Kedström LM, Shabanpoor F, Hossain MA, Clark RJ, Ryan PJ, Craik DJ, Gundlach AL, Wade JD, Bathgate RA and Rosengren KJ. (2011) Design, synthesis, and characterization of a single-chain peptide antagonist for the relaxin-3 receptor RXFP3. J Am Chem Soc 133: 4965-74 [PMID:21384867]

89. Haugaard-Kedström LM, Wong LL, Bathgate RA and Rosengren KJ. (2015) Synthesis and pharmacological characterization of a europium-labelled single-chain antagonist for binding studies of the relaxin-3 receptor RXFP3. Amino Acids 47: 1267-71 [PMID:25792111]

90. Heng K, Ivell R, Wagaarachchi P and Anand-Ivell R. (2008) Relaxin signalling in primary cultures of human myometrial cells. Mol Hum Reprod 14: 603-11 [PMID:18805799]

91. Hoare BL, Bruell S, Sethi A, Gooley PR, Lew MJ, Hossain MA, Inoue A, Scott DJ and Bathgate RAD. (2019) Multi-Component Mechanism of H2 Relaxin Binding to RXFP1 through NanoBRET Kinetic Analysis. iScience 11: 93-113 [PMID:30594862]

92. Hombach-Klonisch S, Bialek J, Trojanowicz B, Weber E, Holzhausen HJ, Silvertown JD, Summerlee AJ, Dralle H, Hoang-Vu C and Klonisch T. (2006) Relaxin enhances the oncogenic potential of human thyroid carcinoma cells. Am J Pathol 169: 617-32 [PMID:16877360]

93. Hombach-Klonisch S, Hoang-Vu C, Kehlen A, Hinze R, Holzhausen HJ, Weber E, Fischer B, Dralle H and Klonisch T. (2003) INSL-3 is expressed in human hyperplastic and neoplastic thyrocytes. Int J Oncol 22: 993-1001 [PMID:12684664]

94. Hosken IT, Sutton SW, Smith CM and Gundlach AL. (2015) Relaxin-3 receptor (Rxfp3) gene knockout mice display reduced running wheel activity: Implications for role of relaxin-3/RXFP3 signalling in sustained arousal. Behav Brain Res 278: 167-75 [PMID:25257104]

95. Hossain MA, Kocan M, Yao ST, Royce SG, Nair VB, Siwek C, Patil NA, Harrison IP, Rosengren KJ and Selemidis S et al.. (2016) A single-chain derivative of the relaxin hormone is a functionally selective agonist of the G protein-coupled receptor, RXFP1. Chem Sci 7: 3805-3819 [PMID:30155023]

96. Hossain MA, Kocan M, Yao ST, Royce SG, Nair VB, Siwek C, Patil NA, Harrison IP, Rosengren KJ and Selemidis S et al.. (2016) A single-chain derivative of the relaxin hormone is a functionally selective agonist of the G protein-coupled receptor, RXFP1. Chem Sci 7: 3805-3819 [PMID:30155023]

97. Hossain MA, Rosengren KJ, Haugaard-Jönsson LM, Zhang S, Layfield S, Ferraro T, Daly NL, Tregear GW, Wade JD and Bathgate RA. (2008) The A-chain of human relaxin family peptides has distinct roles in the binding and activation of the different relaxin family peptide receptors. $J$ Biol Chem 283: 17287-97 [PMID:18434306]

98. Hossain MA, Rosengren KJ, Samuel CS, Shabanpoor F, Chan LJ, Bathgate RA and Wade JD. (2011) The minimal active structure of human relaxin-2.J Biol Chem 286: 37555-65 [PMID:21878627]

99. Hossain MA, Rosengren KJ, Zhang S, Bathgate RA, Tregear GW, van Lierop BJ, Robinson AJ and Wade JD. (2009) Solid phase synthesis and structural analysis of novel A-chain dicarba analogs of human relaxin-3 (INSL7) that exhibit full biological activity. Org Biomol Chem 7: 1547-53 [PMID:19343240]

100. Hossain MA, Samuel CS, Binder C, Hewitson TD, Tregear GW, Wade JD and Bathgate RA. (2010) The chemically synthesized human relaxin-2 analog, B-R13/17K H2, is an RXFP1 antagonist. Amino Acids 39: 409-16 [PMID:20043231]

101. Hsu CJ, McCormack SM and Sanborn BM. (1985) The effect of relaxin on cyclic adenosine 3',5'monophosphate concentrations in rat myometrial cells in culture. Endocrinology 116: 2029-35 [PMID:2985368]

102. Hsu SY, Kudo M, Chen T, Nakabayashi K, Bhalla A, van der Spek PJ, van Duin M and Hsueh AJ. (2000) The three subfamilies of leucine-rich repeat-containing $G$ protein-coupled receptors (LGR): identification of LGR6 and LGR7 and the signaling mechanism for LGR7. Mol Endocrinol 14: 1257-71 [PMID:10935549]

103. Hsu SY, Nakabayashi K, Nishi S, Kumagai J, Kudo M, Sherwood OD and Hsueh AJ. (2002) Activation of orphan receptors by the hormone relaxin. Science 295: 671-4 [PMID:11809971]

104. Hu MJ, Wei D, Shao XX, Wang JH, Liu YL, Xu ZG and Guo ZY. (2017) Interaction mechanism of insulin-like peptide 5 with relaxin family peptide receptor 4. Arch Biochem Biophys 619: 27-34 [PMID:28274616]

105. Hu X, Myhr C, Huang Z, Xiao J, Barnaeva E, Ho BA, Agoulnik IU, Ferrer M, Marugan JJ and Southall $N$ et al.. (2016) Structural Insights into the Activation of Human Relaxin Family Peptide Receptor 1 by Small-Molecule Agonists. Biochemistry 55: 1772-83 [PMID:26866459]

106. Ivell R and Anand-Ivell R. (2018) Insulin-like peptide 3 (INSL3) is a major regulator of female reproductive physiology. Hum Reprod Update 24: 639-651 [PMID:30204868]

107. Ivell $\mathrm{R}$, Balvers $\mathrm{M}$, Pohnke $\mathrm{Y}$, Telgmann $\mathrm{R}$, Bartsch $\mathrm{O}$, Milde-Langosch $\mathrm{K}$, Bamberger AM and 
Einspanier A. (2003) Immunoexpression of the relaxin receptor LGR7 in breast and uterine tissues of humans and primates. Reprod Biol Endocrinol 1: 114 [PMID:14633277]

108. Ivell R and Bathgate R. (2006) Neohormone systems as exciting targets for drug development. Trends Endocrinol Metab 17: 123 [PMID:16580223]

109. Ivell R, Kotula-Balak M, Glynn D, Heng K and Anand-Ivell R. (2011) Relaxin family peptides in the male reproductive system--a critical appraisal. Mol Hum Reprod 17: 71-84 [PMID:20952422]

110. Jeyabalan A, Novak J, Danielson LA, Kerchner LJ, Opett SL and Conrad KP. (2003) Essential role for vascular gelatinase activity in relaxin-induced renal vasodilation, hyperfiltration, and reduced myogenic reactivity of small arteries. Circ Res 93: 1249-57 [PMID:14593002]

111. Kaftanovskaya EM, Ng HH, Soula M, Rivas B, Myhr C, Ho BA, Cervantes BA, Shupe TD, Devarasetty $\mathrm{M}$ and $\mathrm{Hu} \mathrm{X}$ et al.. (2019) Therapeutic effects of a small molecule agonist of the relaxin receptor ML290 in liver fibrosis. FASEB J 33: 12435-12446 [PMID:31419161]

112. Kakouris H, Eddie LW and Summers RJ. (1992) Cardiac effects of relaxin in rats. Lancet 339: 1076-8 [PMID:1349104]

113. Kamat AA, Feng S, Agoulnik IU, Kheradmand F, Bogatcheva NV, Coffey D, Sood AK and Agoulnik AI. (2006) The role of relaxin in endometrial cancer. Cancer Biol Ther 5: 71-7 [PMID:16322684]

114. Kamat AA, Feng S, Bogatcheva NV, Truong A, Bishop CE and Agoulnik AI. (2004) Genetic targeting of relaxin and insulin-like factor 3 receptors in mice. Endocrinology 145: 4712-20 [PMID:15256493]

115. Kania A, Gugula A, Grabowiecka A, de Ávila C, Blasiak T, Rajfur Z, Lewandowski MH, Hess G, Timofeeva E and Gundlach AL et al.. (2017) Inhibition of oxytocin and vasopressin neuron activity in rat hypothalamic paraventricular nucleus by relaxin-3-RXFP3 signalling. $J$ Physiol (Lond.) 595: 3425-3447 [PMID:28098344]

116. Kania A, Szlaga A, Sambak P, Gugula A, Blasiak E, Micioni Di Bonaventura MV, Hossain MA, Cifani C, Hess G and Gundlach AL et al.. (2020) RLN3/RXFP3 Signaling in the PVN Inhibits Magnocellular Neurons via M-like Current Activation and Contributes to Binge Eating Behavior. J Neurosci 40: 5362-5375 [PMID:32532885]

117. Kawamura K, Kumagai J, Sudo S, Chun SY, Pisarska M, Morita H, Toppari J, Fu P, Wade JD and Bathgate RA et al.. (2004) Paracrine regulation of mammalian oocyte maturation and male germ cell survival. Proc Natl Acad Sci USA 101: 7323-8 [PMID:15123806]

118. Khalaf MS, Coles MP and Hitchcock PB. (2008) A structural, theoretical and coordinative evaluation of the bicyclic guanidinate derived from 1,4,6-triazabicyclo[3.3.0]oct-4-ene. Dalton Trans: 4288-95 [PMID:18682868]

119. Klonisch T, Müller-Huesmann H, Riedel M, Kehlen A, Bialek J, Radestock Y, Holzhausen HJ, Steger K, Ludwig M and Weidner W et al.. (2005) INSL3 in the benign hyperplastic and neoplastic human prostate gland. Int J Oncol 27: 307-15 [PMID:16010410]

120. Kocan M, Sarwar M, Hossain MA, Wade JD and Summers RJ. (2014) Signalling profiles of H3 relaxin, $\mathrm{H} 2$ relaxin and $\mathrm{R} 3(\mathrm{~B} \Delta 23-27) \mathrm{R} / \mathrm{I} 5$ acting at the relaxin family peptide receptor 3 (RXFP3). Br J Pharmacol 171: 2827-41 [PMID:24641548]

121. Kohsaka T, Min G, Lukas G, Trupin S, Campbell ET and Sherwood OD. (1998) Identification of specific relaxin-binding cells in the human female. Biol Reprod 59: 991-9 [PMID:9746753]

122. Kompa AR, Samuel CS and Summers RJ. (2002) Inotropic responses to human gene 2 (B29) relaxin in a rat model of myocardial infarction (MI): effect of pertussis toxin. Br J Pharmacol 137: 710-8 [PMID:12381685]

123. Krajnc-Franken MA, van Disseldorp AJ, Koenders JE, Mosselman S, van Duin M and Gossen JA. (2004) Impaired nipple development and parturition in LGR7 knockout mice. Mol Cell Biol 24: 687-96 [PMID:14701741]

124. Kubota Y, Temelcos C, Bathgate RA, Smith KJ, Scott D, Zhao C and Hutson JM. (2002) The role of insulin 3, testosterone, Müllerian inhibiting substance and relaxin in rat gubernacular growth. Mol Hum Reprod 8: 900-5 [PMID:12356938]

125. Kuei C, Sutton S, Bonaventure P, Pudiak C, Shelton J, Zhu J, Nepomuceno D, Wu J, Chen J and Kamme F et al.. (2007) R3(BDelta23 27)R/I5 chimeric peptide, a selective antagonist for GPCR135 and GPCR142 over relaxin receptor LGR7: in vitro and in vivo characterization. $J$ Biol Chem 282: 25425-35 [PMID:17606621]

126. Kuenzi MJ and Sherwood OD. (1995) Immunohistochemical localization of specific relaxinbinding cells in the cervix, mammary glands, and nipples of pregnant rats. Endocrinology 136: 1367-73 [PMID:7895647]

127. Kumagai J, Hsu SY, Matsumi H, Roh JS, Fu P, Wade JD, Bathgate RA and Hsueh AJ. (2002) INSL3/Leydig insulin-like peptide activates the LGR8 receptor important in testis descent. J Biol Chem 277: 31283-6 [PMID:12114498]

128. Kuznetsova L, Plesneva S, Derjabina N, Omeljaniuk E and Pertseva M. (1999) On the mechanism of relaxin action: the involvement of adenylyl cyclase signalling system. Regul Pept 80: 33-9 [PMID:10235632]

129. Lassus J, Harjola VP, Sund R, Siirilä-Waris K, Melin J, Peuhkurinen K, Pulkki K, Nieminen MS 
and FINN-AKVA Study group. (2007) Prognostic value of cystatin C in acute heart failure in relation to other markers of renal function and NT-proBNP. Eur Heart J 28: 1841-7 [PMID:17289743]

130. Lee HS, Postan M, Song A, Clark RJ, Bathgate RAD, Haugaard-Kedström LM and Rosengren KJ. (2020) Development of Relaxin-3 Agonists and Antagonists Based on Grafted Disulfide-Stabilized Scaffolds. Front Chem 8: 87 [PMID:32133341]

131. Lenglos C, Mitra A, Guèvremont $G$ and Timofeeva E. (2013) Sex differences in the effects of chronic stress and food restriction on body weight gain and brain expression of CRF and relaxin3 in rats. Genes Brain Behav 12: 370-87 [PMID:23425370]

132. Lin GY, Lin L, Cai XQ, Dai AT, Zhu Y, Li J, Liu Q, Yang DH, Bathgate RAD and Wang MW. (2020) High-throughput screening campaign identifies a small molecule agonist of the relaxin family peptide receptor 4. Acta Pharmacol Sin 41: 1328-1336 [PMID:32235863]

133. Liu C, Chen J, Kuei C, Sutton S, Nepomuceno D, Bonaventure P and Lovenberg TW. (2005) Relaxin-3/insulin-like peptide 5 chimeric peptide, a selective ligand for G protein-coupled receptor (GPCR)135 and GPCR142 over leucine-rich repeat-containing G protein-coupled receptor 7. Mol Pharmacol 67: 231-40 [PMID:15465925]

134. Liu C, Chen J, Sutton S, Roland B, Kuei C, Farmer N, Sillard R and Lovenberg TW. (2003) Identification of relaxin-3/INSL7 as a ligand for GPCR142. J Biol Chem 278: 50765-70 [PMID:14522967]

135. Liu C, Eriste E, Sutton S, Chen J, Roland B, Kuei C, Farmer N, Jörnvall H, Sillard R and Lovenberg TW. (2003) Identification of relaxin-3/INSL7 as an endogenous ligand for the orphan G-protein-coupled receptor GPCR135. J Biol Chem 278: 50754-64 [PMID:14522968]

136. Liu C, Kuei C, Sutton S, Chen J, Bonaventure P, Wu J, Nepomuceno D, Kamme F, Tran DT and Zhu J et al.. (2005) INSL5 is a high affinity specific agonist for GPCR142 (GPR100). J Biol Chem 280: 292-300 [PMID:15525639]

137. Lowndes K, Amano A, Yamamoto SY and Bryant-Greenwood GD. (2006) The human relaxin receptor (LGR7): expression in the fetal membranes and placenta. Placenta 27: 610-8 [PMID:16165207]

138. Luna JJ, Riesewijk A, Horcajadas JA, Van Os Rd Rd, Domínguez F, Mosselman S, Pellicer A and Simón C. (2004) Gene expression pattern and immunoreactive protein localization of LGR7 receptor in human endometrium throughout the menstrual cycle. Mol Hum Reprod 10: 85-90 [PMID:14742692]

139. Luo X, Li T, Zhu Y, Dai Y, Zhao J, Guo ZY and Wang MW. (2015) The insulinotrophic effect of insulin-like peptide 5 in vitro and in vivo. Biochem J 466: 467-73 [PMID:25514935]

140. Ma J, Niu M, Yang W, Zang L and Xi Y. (2013) Role of relaxin-2 in human primary osteosarcoma. Cancer Cell Int 13: 59 [PMID:23758748]

141. Ma S, Bonaventure P, Ferraro T, Shen PJ, Burazin TC, Bathgate RA, Liu C, Tregear GW, Sutton SW and Gundlach AL. (2007) Relaxin-3 in GABA projection neurons of nucleus incertus suggests widespread influence on forebrain circuits via G-protein-coupled receptor-135 in the rat. Neuroscience 144: 165-90 [PMID:17071007]

142. Ma S, Olucha-Bordonau FE, Hossain MA, Lin F, Kuei C, Liu C, Wade JD, Sutton SW, Nuñez A and Gundlach AL. (2009) Modulation of hippocampal theta oscillations and spatial memory by relaxin-3 neurons of the nucleus incertus. Learn Mem 16: 730-42 [PMID:19880588]

143. Ma S, Shen PJ, Burazin TC, Tregear GW and Gundlach AL. (2006) Comparative localization of leucine-rich repeat-containing G-protein-coupled receptor-7 (RXFP1) mRNA and [33P]-relaxin binding sites in rat brain: restricted somatic co-expression a clue to relaxin action? Neuroscience 141: 329-44 [PMID:16725278]

144. Ma S, Smith CM, Blasiak A and Gundlach AL. (2017) Distribution, physiology and pharmacology of relaxin-3/RXFP3 systems in brain. Br J Pharmacol 174: 1034-1048 [PMID:27774604]

145. Marwari S, Poulsen A, Shih N, Lakshminarayanan R, Kini RM, Johannes CW, Dymock BW and Dawe GS. (2019) Intranasal administration of a stapled relaxin-3 mimetic has anxiolytic- and antidepressant-like activity in rats. Br J Pharmacol 176: 3899-3923 [PMID:31220339]

146. Maseelall PB, Seungdamrong A, Weiss G, Wojtczuk AS, Donnelly R, Stouffer RL and Goldsmith LT. (2009) Expression of LGR7 in the primate corpus luteum implicates the corpus luteum as a relaxin target organ. Ann N Y Acad Sci 1160: 147-51 [PMID:19416177]

147. Matsumoto M, Kamohara M, Sugimoto T, Hidaka K, Takasaki J, Saito T, Okada M, Yamaguchi T and Furuichi K. (2000) The novel G-protein coupled receptor SALPR shares sequence similarity with somatostatin and angiotensin receptors. Gene 248: 183-9 [PMID:10806363]

148. Mazella J, Tang M and Tseng L. (2004) Disparate effects of relaxin and TGFbeta1: relaxin increases, but TGFbeta1 inhibits, the relaxin receptor and the production of IGFBP-1 in human endometrial stromal/decidual cells. Hum Reprod 19: 1513-8 [PMID:15155604]

149. McGowan BM, Stanley SA, Smith KL, Minnion JS, Donovan J, Thompson EL, Patterson M, Connolly MM, Abbott CR and Small CJ et al.. (2006) Effects of acute and chronic relaxin-3 on food intake and energy expenditure in rats. Regul Pept 136: 72-7 [PMID:16764952]

150. McGowan BM, Stanley SA, Smith KL, White NE, Connolly MM, Thompson EL, Gardiner JV, 
Murphy KG, Ghatei MA and Bloom SR. (2005) Central relaxin-3 administration causes hyperphagia in male Wistar rats. Endocrinology 146: 3295-300 [PMID:15845619]

151. McGuane JT, Debrah JE, Sautina L, Jarajapu YP, Novak J, Rubin JP, Grant MB, Segal M and Conrad KP. (2011) Relaxin induces rapid dilation of rodent small renal and human subcutaneous arteries via PI3 kinase and nitric oxide. Endocrinology 152: 2786-96 [PMID:21558316]

152. Metra M, Bettari L, Pagani F, Lazzarini V, Lombardi C, Carubelli V, Bonetti G, Bugatti S, Parrinello G and Caimi L et al.. (2012) Troponin T levels in patients with acute heart failure: clinical and prognostic significance of their detection and release during hospitalisation. Clin Res Cardiol 101: 663-72 [PMID:22407461]

153. Mookerjee I, Hewitson TD, Halls ML, Summers RJ, Mathai ML, Bathgate RA, Tregear GW and Samuel CS. (2009) Relaxin inhibits renal myofibroblast differentiation via RXFP1, the nitric oxide pathway, and Smad2. FASEB J 23: 1219-29 [PMID:19073841]

154. Mookerjee I, Solly NR, Royce SG, Tregear GW, Samuel CS and Tang ML. (2006) Endogenous relaxin regulates collagen deposition in an animal model of allergic airway disease.

Endocrinology 147: 754-61 [PMID:16254028]

155. Muda M, He C, Martini PG, Ferraro T, Layfield S, Taylor D, Chevrier C, Schweickhardt R, Kelton $\mathrm{C}$ and Ryan PL et al.. (2005) Splice variants of the relaxin and INSL3 receptors reveal unanticipated molecular complexity. Mol Hum Reprod 11: 591-600 [PMID:16051677]

156. Munro J, Skrobot O, Sanyoura M, Kay V, Susce MT, Glaser PE, de Leon J, Blakemore AI and Arranz MJ. (2012) Relaxin polymorphisms associated with metabolic disturbance in patients treated with antipsychotics. J Psychopharmacol (Oxford) 26: 374-9 [PMID:21693553]

157. Nef S and Parada LF. (1999) Cryptorchidism in mice mutant for Insl3. Nat Genet 22: 295-9 [PMID:10391220]

158. Neschadim A, Pritzker LB, Pritzker KP, Branch DR, Summerlee AJ, Trachtenberg J and Silvertown JD. (2014) Relaxin receptor antagonist AT-001 synergizes with docetaxel in androgen-independent prostate xenografts. Endocr Relat Cancer 21: 459-71 [PMID:24812057]

159. Nguyen BT and Dessauer CW. (2005) Relaxin stimulates cAMP production in MCF-7 cells upon overexpression of type V adenylyl cyclase. Ann N Y Acad Sci 1041: 296-9 [PMID:15956721]

160. Nguyen BT and Dessauer CW. (2005) Relaxin stimulates protein kinase C zeta translocation: requirement for cyclic adenosine 3',5'-monophosphate production. Mol Endocrinol 19: 1012-23 [PMID:15604116]

161. Nguyen BT, Yang L, Sanborn BM and Dessauer CW. (2003) Phosphoinositide 3-kinase activity is required for biphasic stimulation of cyclic adenosine 3',5'-monophosphate by relaxin. Mol Endocrinol 17: 1075-84 [PMID:12595573]

162. Nistri S and Bani D. (2003) Relaxin receptors and nitric oxide synthases: search for the missing link. Reprod Biol Endocrinol 1: 5-5 [PMID:12646076]

163. Osa $T$, Inoue $H$ and Okabe K. (1991) Effects of porcine relaxin on contraction, membrane response and cyclic AMP content in rat myometrium in comparison with the effects of isoprenaline and forskolin. Br J Pharmacol 104: 950-60 [PMID:1687369]

164. Osheroff PL, Ling VT, Vandlen RL, Cronin MJ and Lofgren JA. (1990) Preparation of biologically active 32P-labeled human relaxin. Displaceable binding to rat uterus, cervix, and brain. J Biol Chem 265: 9396-401 [PMID:2160976]

165. Overbeek PA, Gorlov IP, Sutherland RW, Houston JB, Harrison WR, Boettger-Tong HL, Bishop CE and Agoulnik AI. (2001) A transgenic insertion causing cryptorchidism in mice. Genesis 30: 26-35 [PMID:11353515]

166. Parsell DA, Mak JY, Amento EP and Unemori EN. (1996) Relaxin binds to and elicits a response from cells of the human monocytic cell line, THP-1. J Biol Chem 271: 27936-41 [PMID:8910395]

167. Patil NA, Hughes RA, Rosengren KJ, Kocan M, Ang SY, Tailhades J, Separovic F, Summers RJ, Grosse J and Wade JD et al.. (2016) Engineering of a Novel Simplified Human Insulin-Like Peptide 5 Agonist. J Med Chem 59: 2118-25 [PMID:26824523]

168. Pelusi C, Fanelli F, Pariali M, Zanotti L, Gambineri A and Pasquali R. (2013) Parallel variations of insulin-like peptide 3 (INSL3) and antimüllerian hormone (AMH) in women with the polycystic ovary syndrome according to menstrual cycle pattern. J Clin Endocrinol Metab 98: E1575-82 [PMID:23928669]

169. Petersen LK, Svane D, Uldbjerg N and Forman A. (1991) Effects of human relaxin on isolated rat and human myometrium and uteroplacental arteries. Obstet Gynecol 78: 757-62 [PMID:1923192]

170. Piccenna L, Shen PJ, Ma S, Burazin TC, Gossen JA, Mosselman S, Bathgate RA and Gundlach AL. (2005) Localization of LGR7 gene expression in adult mouse brain using LGR7 knock-out/LacZ knock-in mice: correlation with LGR7 mRNA distribution. Ann N Y Acad Sci 1041: 197-204 [PMID:15956708]

171. Pini A, Shemesh R, Samuel CS, Bathgate RA, Zauberman A, Hermesh C, Wool A, Bani D and Rotman G. (2010) Prevention of bleomycin-induced pulmonary fibrosis by a novel antifibrotic peptide with relaxin-like activity. J Pharmacol Exp Ther 335: 589-99 [PMID:20826567]

172. Ryan PJ, Büchler E, Shabanpoor F, Hossain MA, Wade JD, Lawrence AJ and Gundlach AL. (2013) 
Central relaxin-3 receptor (RXFP3) activation decreases anxiety- and depressive-like behaviours in the rat. Behav Brain Res 244: 142-51 [PMID:23380674]

173. Ryan PJ, Kastman HE, Krstew EV, Rosengren KJ, Hossain MA, Churilov L, Wade JD, Gundlach AL and Lawrence AJ. (2013) Relaxin-3/RXFP3 system regulates alcohol-seeking. Proc Natl Acad Sci USA 110: 20789-94 [PMID:24297931]

174. Rytova V, Ganella DE, Hawkes D, Bathgate RAD, Ma S and Gundlach AL. (2019) Chronic activation of the relaxin-3 receptor on GABA neurons in rat ventral hippocampus promotes anxiety and social avoidance. Hippocampus 29: 905-920 [PMID:30891856]

175. Samuel CS. (2005) Relaxin: antifibrotic properties and effects in models of disease. Clin Med Res 3: 241-9 [PMID:16303890]

176. Samuel CS, Unemori EN, Mookerjee I, Bathgate RA, Layfield SL, Mak J, Tregear GW and Du XJ. (2004) Relaxin modulates cardiac fibroblast proliferation, differentiation, and collagen production and reverses cardiac fibrosis in vivo. Endocrinology 145: 4125-33 [PMID:15155573]

177. Samuel CS, Zhao C, Bathgate RA, Bond CP, Burton MD, Parry LJ, Summers RJ, Tang ML, Amento EP and Tregear GW. (2003) Relaxin deficiency in mice is associated with an age-related progression of pulmonary fibrosis. FASEB J 17: 121-3 [PMID:12424226]

178. Samuel CS, Zhao C, Bathgate RA, DU XJ, Summers RJ, Amento EP, Walker LL, McBurnie M, Zhao L and Tregear GW. (2005) The relaxin gene-knockout mouse: a model of progressive fibrosis. Ann N Y Acad Sci 1041: 173-181 [PMID:15956703]

179. Sanborn BM, Kuo HS, Weisbrodt NW and Sherwood OD. (1980) The interaction of relaxin with the rat uterus. I. Effect on cyclic nucleotide levels and spontaneous contractile activity. Endocrinology 106: 1210-5 [PMID:6244146]

180. Sarwar M, Samuel CS, Bathgate RA, Stewart DR and Summers RJ. (2015) Serelaxin-mediated signal transduction in human vascular cells: bell-shaped concentration-response curves reflect differential coupling to G proteins. Br J Pharmacol 172: 1005-19 [PMID:25297987]

181. Sarwar M, Samuel CS, Bathgate RA, Stewart DR and Summers RJ. (2016) Enhanced serelaxin signalling in co-cultures of human primary endothelial and smooth muscle cells. Br J Pharmacol 173: 484-96 [PMID:26493539]

182. Sassoli C, Chellini F, Pini A, Tani A, Nistri S, Nosi D, Zecchi-Orlandini S, Bani D and Formigli L. (2013) Relaxin prevents cardiac fibroblast-myofibroblast transition via notch-1-mediated inhibition of TGF-ß/Smad3 signaling. PLoS ONE 8: e63896 [PMID:23704950]

183. Scott DJ, Fu P, Shen PJ, Gundlach A, Layfield S, Riesewijk A, Tomiyama H, Hutson JM, Tregear GW and Bathgate RA. (2005) Characterization of the rat INSL3 receptor. Ann N Y Acad Sci 1041: 13-6 [PMID:15956681]

184. Scott DJ, Layfield S, Riesewijk A, Morita H, Tregear GW and Bathgate RA. (2005) Characterization of the mouse and rat relaxin receptors. Ann N Y Acad Sci 1041: 8-12 [PMID:15956680]

185. Scott DJ, Layfield S, Riesewijk A, Morita H, Tregear GW and Bathgate RA. (2004) Identification and characterization of the mouse and rat relaxin receptors as the novel orthologues of human leucine-rich repeat-containing G-protein-coupled receptor 7. Clin Exp Pharmacol Physiol 31: 828-32 [PMID:15566402]

186. Scott DJ, Layfield S, Yan Y, Sudo S, Hsueh AJ, Tregear GW and Bathgate RA. (2006) Characterization of novel splice variants of LGR7 and LGR8 reveals that receptor signaling is mediated by their unique low density lipoprotein class A modules. J Biol Chem 281: 34942-54 [PMID:16963451]

187. Scott DJ, Tregear GW and Bathgate RA. (2005) LGR7-truncate is a splice variant of the relaxin receptor LGR7 and is a relaxin antagonist in vitro. Ann N Y Acad Sci 1041: 22-6 [PMID:15956683]

188. Sedaghat K, Shen PJ, Finkelstein DI, Henderson JM and Gundlach AL. (2008) Leucine-rich repeat-containing G-protein-coupled receptor 8 in the rat brain: Enrichment in thalamic neurons and their efferent projections. Neuroscience 156: 319-33 [PMID:18706979]

189. Sethi A, Bruell S, Patil N, Hossain MA, Scott DJ, Petrie EJ, Bathgate RA and Gooley PR. (2016) The complex binding mode of the peptide hormone H2 relaxin to its receptor RXFP1. Nat Commun 7: 11344 [PMID:27088579]

190. Shabanpoor F, Akhter Hossain M, Ryan PJ, Belgi A, Layfield S, Kocan M, Zhang S, Samuel CS, Gundlach AL and Bathgate RA et al.. (2012) Minimization of human relaxin-3 leading to highaffinity analogues with increased selectivity for relaxin-family peptide 3 receptor (RXFP3) over RXFP1.J Med Chem 55: 1671-81 [PMID:22257012]

191. Shabanpoor F, Bathgate RA, Belgi A, Chan LJ, Nair VB, Wade JD and Hossain MA. (2012) Sitespecific conjugation of a lanthanide chelator and its effects on the chemical synthesis and receptor binding affinity of human relaxin-2 hormone. Biochem Biophys Res Commun 420: 2536 [PMID:22425984]

192. Shabanpoor F, Bathgate RA, Hossain MA, Giannakis E, Wade JD and Hughes RA. (2007) Design, synthesis and pharmacological evaluation of cyclic mimetics of the insulin-like peptide 3 (INSL3) B-chain. J Pept Sci 13: 113-20 [PMID:17120268] 
193. Shabanpoor F, Hughes RA, Bathgate RA, Zhang S, Scanlon DB, Lin F, Hossain MA, Separovic F and Wade JD. (2008) Solid-phase synthesis of europium-labeled human INSL3 as a novel probe for the study of ligand-receptor interactions. Bioconjug Chem 19: 1456-63 [PMID:18529069]

194. Shabanpoor F, Zhang S, Hughes RA, Hossain MA, Layfield S, Ferraro T, Bathgate RA, Separovic F and Wade JD. (2011) Design and development of analogues of dimers of insulin-like peptide 3 B-chain as high-affinity antagonists of the RXFP2 receptor. Biopolymers 96: 81-7 [PMID:20560146]

195. Shah R, Gayat E, Januzzi Jr JL, Sato N, Cohen-Solal A, diSomma S, Fairman E, Harjola VP, Ishihara S and Lassus J et al.. (2014) Body mass index and mortality in acutely decompensated heart failure across the world: a global obesity paradox. J Am Coll Cardiol 63: 778-85 [PMID:24315906]

196. Shemesh R, Toporik A, Levine Z, Hecht I, Rotman G, Wool A, Dahary D, Gofer E, Kliger Y and Soffer MA et al.. (2008) Discovery and validation of novel peptide agonists for G-protein-coupled receptors. J Biol Chem 283: 34643-9 [PMID:18854305]

197. Shen PJ, Fu P, Phelan KD, Scott DJ, Layfield S, Tregear GW, Bathgate RA and Gundlach AL. (2005) Restricted expression of LGR8 in intralaminar thalamic nuclei of rat brain suggests a role in sensorimotor systems. Ann N Y Acad Sci 1041: 510-5 [PMID:15956753]

198. Siebel AL, Gehring HM, Reytomas IG and Parry LJ. (2003) Inhibition of oxytocin receptor and estrogen receptor-alpha expression, but not relaxin receptors (LGR7), in the myometrium of late pregnant relaxin gene knockout mice. Endocrinology 144: 4272-5 [PMID:12959965]

199. Smith CM, Chua BE, Zhang C, Walker AW, Haidar M, Hawkes D, Shabanpoor F, Hossain MA, Wade JD and Rosengren KJ et al.. (2014) Central injection of relaxin-3 receptor (RXFP3) antagonist peptides reduces motivated food seeking and consumption in C57BL/6J mice. Behav Brain Res 268: 117-26 [PMID:24681162]

200. Smith CM, Hosken IT, Sutton SW, Lawrence AJ and Gundlach AL. (2012) Relaxin-3 null mutation mice display a circadian hypoactivity phenotype. Genes Brain Behav 11: 94-104 [PMID:21899720]

201. Smith CM, Ryan PJ, Hosken IT, Ma S and Gundlach AL. (2011) Relaxin-3 systems in the brain-the first 10 years. J Chem Neuroanat 42: 262-75 [PMID:21693186]

202. Smith CM, Shen PJ, Banerjee A, Bonaventure P, Ma S, Bathgate RA, Sutton SW and Gundlach AL. (2010) Distribution of relaxin-3 and RXFP3 within arousal, stress, affective, and cognitive circuits of mouse brain. J Comp Neurol 518: 4016-45 [PMID:20737598]

203. Strausberg RL, Feingold EA, Grouse LH, Derge JG, Klausner RD, Collins FS, Wagner L, Shenmen CM, Schuler GD and Altschul SF et al.. (2002) Generation and initial analysis of more than 15,000 full-length human and mouse cDNA sequences. Proc Natl Acad Sci USA 99: 16899903 [PMID:12477932]

204. Sudo S, Kumagai J, Nishi S, Layfield S, Ferraro T, Bathgate RA and Hsueh AJ. (2003) H3 relaxin is a specific ligand for LGR7 and activates the receptor by interacting with both the ectodomain and the exoloop 2. J Biol Chem 278: 7855-62 [PMID:12506116]

205. Sunn N, Egli M, Burazin TC, Burns P, Colvill L, Davern P, Denton DA, Oldfield BJ, Weisinger RS and Rauch $\mathrm{M}$ et al.. (2002) Circulating relaxin acts on subfornical organ neurons to stimulate water drinking in the rat. Proc Natl Acad Sci USA 99: 1701-6 [PMID:11830674]

206. Sutton SW, Bonaventure P, Kuei C, Roland B, Chen J, Nepomuceno D, Lovenberg TW and Liu C. (2004) Distribution of G-protein-coupled receptor (GPCR)135 binding sites and receptor mRNA in the rat brain suggests a role for relaxin-3 in neuroendocrine and sensory processing. Neuroendocrinology 80: 298-307 [PMID:15677880]

207. Tan YY, Wade JD, Tregear GW and Summers RJ. (1998) Comparison of relaxin receptors in rat isolated atria and uterus by use of synthetic and native relaxin analogues. BrJ Pharmacol 123: 762-70 [PMID:9517397]

208. Tan YY, Wade JD, Tregear GW and Summers RJ. (1999) Quantitative autoradiographic studies of relaxin binding in rat atria, uterus and cerebral cortex: characterization and effects of oestrogen treatment. BrJ Pharmacol 127: 91-8 [PMID:10369460]

209. Tanaka M, Ijijima N, Miyamoto Y, Fukusumi S, Itoh Y, Ozawa H and Ibata Y. (2005) Neurons expressing relaxin 3/INSL 7 in the nucleus incertus respond to stress. Eur J Neurosci 21: 165970 [PMID:15845093]

210. Tang XM and Chegini N. (1995) Human fallopian tube as an extraovarian source of relaxin: messenger ribonucleic acid expression and cellular localization of immunoreactive protein and 125I-relaxin binding sites. Biol Reprod 52: 1343-9 [PMID:7543297]

211. Tashima LS, Mazoujian G and Bryant-Greenwood GD. (1994) Human relaxins in normal, benign and neoplastic breast tissue. J Mol Endocrinol 12: 351-64 [PMID:7916973]

212. Teerlink JR, Cotter G, Davison BA, Felker GM, Filippatos G, Greenberg BH, Ponikowski P, Unemori E, Voors AA and Adams Jr KF et al.. (2013) Serelaxin, recombinant human relaxin-2, for treatment of acute heart failure (RELAX-AHF): a randomised, placebo-controlled trial. Lancet 381: 29-39 [PMID:23141816]

213. Teerlink JR, Metra M, Felker GM, Ponikowski P, Voors AA, Weatherley BD, Marmor A, Katz A, 
Grzybowski J and Unemori E et al.. (2009) Relaxin for the treatment of patients with acute heart failure (Pre-RELAX-AHF): a multicentre, randomised, placebo-controlled, parallel-group, dosefinding phase IIb study. Lancet 373: 1429-39 [PMID:19329178]

214. Thompson VC, Morris TG, Cochrane DR, Cavanagh J, Wafa LA, Hamilton T, Wang S, Fazli L, Gleave ME and Nelson CC. (2006) Relaxin becomes upregulated during prostate cancer progression to androgen independence and is negatively regulated by androgens. Prostate $\mathbf{6 6}$ : 1698-709 [PMID:16998820]

215. van der Westhuizen ET, Christopoulos A, Sexton PM, Wade JD and Summers RJ. (2010) H2 relaxin is a biased ligand relative to $\mathrm{H} 3$ relaxin at the relaxin family peptide receptor 3 (RXFP3). Mol Pharmacol 77: 759-72 [PMID:20159943]

216. Van der Westhuizen ET, Sexton PM, Bathgate RA and Summers RJ. (2005) Responses of GPCR135 to human gene 3 (H3) relaxin in CHO-K1 cells determined by microphysiometry. Ann N Y Acad Sci 1041: 332-7 [PMID:15956730]

217. Van Der Westhuizen ET, Summers RJ, Halls ML, Bathgate RA and Sexton PM. (2007) Relaxin receptors--new drug targets for multiple disease states. Curr Drug Targets 8: 91-104 [PMID:17266534]

218. van der Westhuizen ET, Werry TD, Sexton PM and Summers RJ. (2007) The relaxin family peptide receptor 3 activates extracellular signal-regulated kinase 1/2 through a protein kinase C-dependent mechanism. Mol Pharmacol 71: 1618-29 [PMID:17351017]

219. Vodstrcil LA, Shynlova O, Verlander JW, Wlodek ME and Parry LJ. (2010) Decreased expression of the rat myometrial relaxin receptor (RXFP1) in late pregnancy is partially mediated by the presence of the conceptus. Biol Reprod 83: 818-24 [PMID:20686184]

220. Vodstrcil LA, Shynlova O, Westcott K, Laker R, Simpson E, Wlodek ME and Parry LJ. (2010) Progesterone withdrawal, and not increased circulating relaxin, mediates the decrease in myometrial relaxin receptor (RXFP1) expression in late gestation in rats. Biol Reprod 83: 825-32 [PMID:20686183]

221. Vodstrcil LA, Wlodek ME and Parry LJ. (2007) Effects of uteroplacental restriction on the relaxin-family receptors, Lgr7 and Lgr8, in the uterus of late pregnant rats. Reprod Fertil Dev 19: 530-8 [PMID:17524297]

222. Walker AW, Smith CM, Chua BE, Krstew EV, Zhang C, Gundlach AL and Lawrence AJ. (2015) Relaxin-3 receptor (RXFP3) signalling mediates stress-related alcohol preference in mice. PLoS ONE 10: e0122504 [PMID:25849482]

223. Wang JH, Hu MJ, Zhang L, Shao XX, Lv CH, Liu YL, Xu ZG and Guo ZY. (2018) Exploring receptor selectivity of the chimeric relaxin family peptide R3/I5 by incorporating unnatural amino acids. Biochimie 154: 77-85 [PMID:30102931]

224. Wilkinson TN, Speed TP, Tregear GW and Bathgate RA. (2005) Evolution of the relaxin-like peptide family. BMC Evol Biol 5: 14 [PMID:15707501]

225. Wong LLL, Scott DJ, Hossain MA, Kaas Q, Rosengren KJ and Bathgate RAD. (2018) Distinct but overlapping binding sites of agonist and antagonist at the relaxin family peptide 3 (RXFP3) receptor. J Biol Chem 293: 15777-15789 [PMID:30131340]

226. Wu QP, Zhang L, Shao XX, Wang JH, Gao Y, Xu ZG, Liu YL and Guo ZY. (2016) Application of the novel bioluminescent ligand-receptor binding assay to relaxin-RXFP1 system for interaction studies. Amino Acids 48: 1099-1107 [PMID:26767372]

227. Xiao J, Chen CZ, Huang Z, Agoulnik IU, Ferrer M, Southall N, Hu X, Zheng W, Agoulnik AI and Marugan JJ. (2010) Discovery, optimization, and biological activity of the first potent and selective small-molecule agonist series of human relaxin receptor 1 (RXFP1). Probe Reports from the NIH Molecular Libraries Program [PMID:23905199]

228. Xiao J, Huang Z, Chen CZ, Agoulnik IU, Southall N, Hu X, Jones RE, Ferrer M, Zheng W and Agoulnik AI et al.. (2013) Identification and optimization of small-molecule agonists of the human relaxin hormone receptor RXFP1. Nat Commun 4: 1953 [PMID:23764525]

229. Xue K, Kim JY, Liu JY and Tsang BK. (2014) Insulin-like 3-induced rat preantral follicular growth is mediated by growth differentiation factor 9. Endocrinology 155: 156-67 [PMID:24169563]

230. Yang S, Rembiesa B, Büllesbach EE and Schwabe C. (1992) Relaxin receptors in mice: demonstration of ligand binding in symphyseal tissues and uterine membrane fragments. Endocrinology 130: 179-85 [PMID:1309327]

231. Yegorov S, Bogerd J and Good SV. (2014) The relaxin family peptide receptors and their ligands: new developments and paradigms in the evolution from jawless fish to mammals. Gen Comp Endocrinol 209: 93-105 [PMID:25079565]

232. Zhang C, Chua BE, Yang A, Shabanpoor F, Hossain MA, Wade JD, Rosengren KJ, Smith CM and Gundlach AL. (2015) Central relaxin-3 receptor (RXFP3) activation reduces elevated, but not basal, anxiety-like behaviour in C57BL/6J mice. Behav Brain Res 292: 125-32 [PMID:26057358]

233. Zhang Q, Liu SH, Erikson M, Lewis M and Unemori E. (2002) Relaxin activates the MAP kinase pathway in human endometrial stromal cells. J Cell Biochem 85: 536-44 [PMID:11967993]

234. Zhang S, Hughes RA, Bathgate RA, Shabanpoor F, Hossain MA, Lin F, van Lierop B, Robinson AJ and Wade JD. (2010) Role of the intra-A-chain disulfide bond of insulin-like peptide 3 in binding 
and activation of its receptor, RXFP2. Peptides 31: 1730-6 [PMID:20570702]

235. Zhu J, Kuei C, Sutton S, Kamme F, Yu J, Bonaventure P, Atack J, Lovenberg TW and Liu C. (2008) Identification of the domains in RXFP4 (GPCR142) responsible for the high affinity binding and agonistic activity of INSL5 at RXFP4 compared to RXFP3 (GPCR135). Eur J Pharmacol 590: 43-52 [PMID:18582868] 